\title{
Pupils' everyday transitions in school as a condition for social relations and activities in leisure time centres
}

Lina Söderman Lago and Helene Elvstrand

The self-archived postprint version of this journal article is available at Linköping University Institutional Repository (DiVA):

http:/ / urn.kb.se/ resolve?urn=urn:nbn:se:liu:diva-140193

N.B.: When citing this work, cite the original publication.

This is an electronic version of an article published in:

Söderman Lago, L., Elvstrand, H., (2017), Pupils' everyday transitions in school as a condition for social relations and activities in leisure time centres, Early years.

https:// doi.org/ 10.1080/ 09575146.2017.1371675

Original publication available at:

https:/ / doi.org/ 10.1080/ 09575146.2017.1371675

Copyright: Taylor \& Francis (Routledge) (SSH Titles)

http:// www.routledge.com/ 
Pupils' everyday transitions in school as a condition for social relations and activities in leisure time centre

Lina Lago, $\mathrm{PhD}$ (corresponding author)

Linköping University, Department of social and welfare studies

SE-601 74 Norrköping

ORCID-id: 0000-0002-4841-9033

e-mail: lina.lago@liu.se

Phone: +4611363303

Helene Elvstrand, PhD

Linköping University, Department of Social and Welfare Studies

SE-601 74 Norrköping

ORCID-id: 0000-0001-6933-5667

e-mail: helene.elvstrand@liu.se

Phone: +46113633 55 


\title{
Pupils' everyday transitions in school as a condition for social relations and activities in leisure time centre
}

\author{
Lina Lago \& Helene Elvstrand
}

\begin{abstract}
This article focuses on how pupils' everyday transitions constitute a condition for pupils' activities and relationships, and how pupils understand and give meaning to their everyday transitions between different school settings (school and Leisure Time Centre). To examine this we made participant observations in three different educational settings. The focus of these observations is on pupils in their everyday life in school and LTC, thereby gaining insight into the experiences of being a pupil in these settings. In regard to social relations, the changes brought about by daily transitions between educational settings, create conditions for different activities and changes in the group. The changes in groups that occur in the different contexts of everyday transitions in school can be both an opportunity and an obstacle, depending on the situation and with whom pupils wish to engage in social interaction. Thus, it is clear that the transition from school to LTC often involves changes in the group, thereby changing the conditions of pupils' opportunities to form relationships with each other.
\end{abstract}

Keywords: Everyday transitions, school, leisure time centre, peer relations, peer cultures

\section{Introduction}

Most pupils in the early school years (6-9 years) attend both preschool class/elementary school ${ }^{1}$ and leisure time centre (LTC). That is, during their school days, pupils attend different types of educational settings. These different types of educational settings have different assignments, histories and methods, and focus on diverse aspects of pupils' learning and wellbeing. At the same time, school and LTC have assignments to cooperate with and complement each other, creating a unit for the pupils (National Agency of Education 2016b). During a day in school and LTC, pupils transition between these different contexts and must act within and make sense of the different social situations that they encounter in these settings.

In this article, the aim is to investigate pupils' everyday transitions between school and LTC as a condition that has an impact on a pupil's opportunities to create social relations. We will

\footnotetext{
${ }^{1}$ Swedish 6-year-olds attend preschool class, which is a specific type of schooling, and begin primary school the year they turn 7. Both preschool class pupils and primary school pupils attend LTC. Henceforth, we use the term 'school' for both preschool class and primary school.
} 
also focus on social relations and activities in the Swedish LTC. More specifically, we ask these questions: What happens regarding pupils' relations and activities as they move from one educational setting to another? How do the daily transitions from school to LTC influence pupils' activities and their relationships with other pupils?

\section{Leisure time centre as a part of the educational system in Sweden}

Most pupils between 6-9 years of age, a total of almost 460000 pupils (National Agency of Education 2016a), take part in LTC (Klerfelt and Haglund 2014). That is, most of these pupils experience 'a school and LTC day' rather than just a school day. In most cases, school and LTC are located in the same facilities, and it is common for the leisure-time pedagogues to work with the same pupils during both school and LTC. School and LTC have the task of cooperating with each other for the pupils' best interests. Knowledge of pupils' transitions between school contexts is important to this assignment, especially in relation to LTC's specific assignment to work with pupils’ social relations (National Agency of Education 2014). Child-initiated group activities and a focus on social relations and social abilities in groups characterize LTC activities (Andersson 2013).

The Education Act (SFS 2010:800) regulates Swedish LTC just as it regulates compulsory school and the preschool class. LTC constitutes a specific social context in pupils' everyday life. In some ways, it is characterized by freer and more varying forms of interaction between pupils than those that occur in school. The Swedish LTC has gone through many changes in recent years, with reforms that emphasize that LTC's main task is to be an educational setting and to complement the school's learning assignments. The groups in LTC is often less stable than the school class with pupils coming and going. The teaching approach in LTC can be characterized as less controlled (National Agency of Education 2014) cause changing conditions for pupils' social relations. LTC often, but not always, involves pupils from different school classes, making the group in LTC different from the group of peers pupils attend school with. This makes LTC a place where pupils follow up on their social relations from school, but also one where they can establish new relations with peers who are not classmates.

School, on the other hand, is often more regulated than LTC, and involves more of a direct teaching approach, with goals in the curriculum that pupils should achieve (National Agency of Education 2016b). As a result, pupils in school have fewer opportunities to choose activities and less time to play and be with friends. Thus, the conditions for social relations 
are different during school hours and LTC hours, although many of the other conditions (e.g. location, teachers, peers) can be fully or partially the same.

\section{Transitions and social relations}

Pupils' social relations are of huge importance to their wellbeing; relations are also constantly ongoing and a part of pupils’ everyday life (cf. Bliding 2004). Former studies of pupils’ social relations have shown the complexity of forming relations in situations where aspects of inclusion, exclusion and different kinds of negotiations are central (Bliding 2004; Dahl 2014; Ihrskog 2006).

Pupils' social relations with respect to school transitions are relevant for this study, since we are interested in the transitions between school and LTC. Some studies have investigated how changing conditions caused by transitions between different contexts influence pupils' social relations (Corsaro, Molinari, Hadley, and Sugioka 2003; Dehnæs Hogsnes 2014; Elvstrand and Närvänen 2014; Johansson 2007; Ledger, Smith, and Rich 2000; Weller 2007). These studies show that pupils' relations, friendships and groups must, to some extent, be redefined when transitions occur between different school contexts. For example, friends may end up in different groups, and there are differences in play activities and teacher control. Lago (2014) shows how the change caused by the transition from preschool class to first grade is something that pupils need in order to give meaning to transitions. In their peer group, pupils negotiate and manage the change brought by daily transitions. According to Ackesjö and Landefrö (2014), pupils describes preschool class and LTC two distinctive and separate identities but describe the daily transition as blurred. It is not always clear to them when one ends and the other begins. The content is understood as different but the activities are sometimes seen as similar. This makes the borders blurred and visible at the same time.

Hvitfeldt Stanek (2011) has focused on transitions between different educational settings in Denmark by studying pupils’ perspectives on transitions. Her study shows that different conditions and possibilities cause various forms of participation. The study also highlights the importance of gaining pupils' perspective on transitions, and emphasizes that the pupils' perspective can differ compared with, for example, the teachers’ perspective.

Some studies address the transition from preschool or home to LTC. Dockett and Perry (2016) show that LTC (or school-age care) can play an important part in pupils' transitions to school and that LTC can be an arena where a sense of belonging can be created in the 
transition to school, partly since LTC is a place to be with friends. Dockett and Perry thus describe the roles of LTC in the transition as 'missed opportunities', since there is often a lack of knowledge about LTC among administrators and little specific information available about LTC.

These studies address transitions between stages or grades over time. The everyday transitions between different educational settings are less studied. Previous research shows that everyday transitions between school and LTC can limit opportunities to be with friends in LTC. Elvstrand and Lago (2016) show that the changing nature of the groups in school and LTC constitutes a limitation in pupils' opportunities to engage in social relations with whomever they want. This article explores these results further in an attempt to better understand pupils' social relations throughout the whole school day.

\section{Theoretical frames}

Educational transitions occur when pupils move between different school settings. Transitions involve changes in status, role identity and/or agency as the conditions for this change. Transitions can be about actual change but also about the idea that change is possible. Such ideas about possible change contribute to how the participants understand the transition and its different contexts. Transition, however, also involves continuity. The contexts between which educational transitions occur have many common features and common or complementary missions, which contribute to continuity. In this way, a transition has both a structural and a meaning-making aspect (Dunlop 2007; Fabian 2007; Lam and Pollard 2006; Niesel and Griebel 2007). A transition is partly about conditions and partly about how people understand and interpret these conditions. In this article, the structural changes are the foundation against which meanings are made. Our focus is on how people, in this case mainly pupils, understand the different contexts that they are a part of during a school day.

Everyday transitions, the kind of transitions that this article focuses on, are educational transitions that occur recurrently during a period of time. These transitions can be described as horizontal transitions - that is, transitions that are repeated daily between, for example, schools and LTC. These transitions differs from vertical transitions - that is, transitions between different marked levels in the school system such as from preschool to school (Broström and Wagner 2003; Wagner 2003). To study these daily transitions or changes, a framework of symbolic interactionism (SI) is used. The main concern of SI is how people define situations in which they participate and how such definitions are negotiated in 
interaction with others. Meaning is formed in the context of social interactions and is derived from these interactions by the actors; the use of these meanings occurs through a process of interpretation (Atkinson and Housley 2003; Blumer 1969; Charon 2007; Närvänen and Näsman 2007). This focus on relations and meaning-making processes is well suited to the aim of this study, since we are interested in a participant perspective on social relations.

In line with SI the concepts social interaction and social relations are used to describe the relationships that pupils have and are given the opportunity to have in school and LTC. Social interaction is the constantly ongoing interactions between people while social relations are built over time, the lasting and recurring interactions if you will. We see these relationships as contextually constructed, and thereby changeable (Hogg and Vaughn 2010; Thornberg 2013).

\section{Methods}

The article builds on participant observations from three different educational settings, which are located in two different mid-sized municipalities in Sweden. The schools are chosen to get a geographical variation (e.g. rural and city) and because they organize school and LTC in different ways. The focus of these observations is on participating with pupils in their everyday life in school and LTC, and thereby gaining insight into their experiences of being a pupil in these settings (cf. Hvitfeldt Stanek 2011). Participant observation involves taking part in someone's life in order to obtain knowledge about what is going on. In this case, we took part in the pupils' different activities in order to see, learn and discuss these activities with the pupils. Participant observation means that the researcher observes at the same time as the participants go through their experiences; It is about understanding what participants see as meaningful (e.g. Emerson, Fretz, and Shaw 1995; Hammersley and Atkinson 2007). Some of the material was obtained during school hours (André School) and some during LTC hours (Riverton School and an LTC centre called The Bear/Monkey). Two of the schools are located in two mid-sized Swedish towns (André school and Bear/Monkey), while the Riverton School is located in a smaller village outside of the city. At André School and Bear/Monkey, the LTC centres consist of pupils in mixed age groups; at Riverton School, the LTC centre is organized in same-age units. In all three schools, school and LTC shared, at least in part, the same premises. The observations at André School took place over a time period of one year and were part of a doctoral thesis (Lago, 2014), while the observations at Riverton School (observations done by both authors) and Bear/Monkey (observations done by Elvstrand) were carried out over a shorter period (4-5 days in each school). At André School the observations were done during school hours while the observations at Riverton School 
and at Bear/Monkey where done mainly during LTC hours. On these occasions, we followed the activities that took place while focusing on pupils' social interaction. Because of the large number of pupils, of course, we could not follow all the pupils. Therefore, our strategy was to move around and observe the various groupings during different activities. The observations were primarily documented with field notes in which events and talk were written down and described. The field notes were analysed by content analysis according to a constructivist grounded theory (GT) approach. In this practically analysed work, we focused on how transitions were made by the actors, and on what kind of meaning the actors put to these transitions. We compared similarities and differences in the field notes and thus constructed different categories based on the empirical material. GT focuses on interaction, meaning and social processes (Charmaz 2014) and is the methodological standpoint for this study. GT assumes that interaction is inherently interpretive, and addresses how people create meanings and actions (Charmaz 2014). In this article, we highlight material that shows how the daily transitions between school and LTC are further explored in relation to pupils' activities and social relations.

\section{Ethical considerations}

Participant observations require constant ethical considerations, due in part to the closeness between the researcher and the participants. Prior to the study, pupils, parents and teachers received information and were asked to give their consent to participation. In the cases were consent was not given by the parents we did not observe situations involving these children and did not take notes when they were around. We also tried to continuously obtain the consent of participating pupils by being responsive to whether or not they wanted to be observed in their activities (cf. Skelton 2008). In cases when the children said or showed (e.g. by body language or shut doors) that our presence was not wanted we did not observe these situations. Overall, however, the children were curious about what we did and asked questions and shared their experiences. When the informants are pupils, it is important to work with issues of power and adult-child relations throughout the study. One way we worked with power relations was by being open to and curious of what the pupils wanted to show. In this way, the pupils became the ones with knowledge and competence, which we often pointed out for them (Mayall 2000). In addition to these efforts, we took the ethical guidelines of the Swedish Research Council into account; for example, all the names used in this study are fictitious. 


\section{Limitations of and possibilities for pupils' social relations in the transition}

\section{from school to after-school care}

During the analysis, two aspects regarding pupils' everyday transitions and their opportunities to engage in different activities and social interactions at LTC were identified as recurring in the material. These aspects were the governance of pupil activities that occurred in the transition to and from LTC, and the influence that the changing groups between schools and LTC had on pupils' opportunities to choose which relationships they wanted to maintain and take part in. Both what to do and whom to be with can be seen as important conditions for pupils' opportunities to form social relations, and both may constitute either an obstacle or an opportunity in shaping a desired relationship. These themes are analysed further below.

\section{Pupils' opportunities to choose an activity}

The opportunity to choose an activity can be seen as an important condition for pupils' social relationships. Research has shown that mutual engagement in an activity can be grounds for social relations, and that different activities are used to negotiate the social order in the peer group (this has been shown to be important in preschool settings; cf. Corsaro 2003; Skånfors 2010). Opportunities to choose, to participate in, and to continue activities before and after an everyday transition are therefore important in relation to pupils’ relationship building. Our field notes contain several examples in which pupils expressed a desire to continuing working on something they did during the school day or during LTC. It was common for the teachers, both in school and in LTC, to deny these requests, saying that that specific activity is something that the pupils do 'when you are in LTC' (or vice versa). In these cases, the teachers and the pupils had different points of view. The pupils expressed a desire for an ongoing activity that was sometimes connected to a relational project. For example, some pupils asked whether they could continue to work on something they had started together, thus also asking for an opportunity to continue their social relations with each other (fieldnotes from Bear/Monkey and André School). In their desire to continue what they were already working on, these students did not distinguish between school and LTC. The teachers, on the other hand, drew on the organization of the school day, where certain activities are 'school activities' and others are 'LTC activities'. For the teachers, school routines seemed to be the most important thing in constructing social order. In cases like these, a conflict arises between the routines and organization of the school day on the one hand, and the pupils' own choices, activities and relations on the other. The teachers can be said to have 'organizational views', 
in which school and LTC are clearly distinguished from each other, while the pupils act from the point of view that the whole school day is a unit.

The opposite can be said to be true in other cases, when pupils who did not attend LTC missed activities that took place during LTC hours. In the example below, the teacher and some pupils in a preschool class discuss being outside. Outside activities were often part of the school day; however, if teachers considered that there was too much to do during school hours, outdoor activities could be withheld.

\section{Example 1}

The class is sitting in the assembly circle. 'Pia, when are we going out?' says Jabir. 'We don’t have time to go out, Jabir', Pia responds. 'Maybe when we have leisure time, maybe we will go out then?' someone suggests. There is a discussion about what should happen at LTC. 'Disco', says someone. 'But we have already had that.' 'We're going to play football.' 'Nah, we're not playing football today', says Pia. 'Shall we go out once we have read the book?' [referring to an LTC activity] the pupils ask. 'Well, we might go out then', Pia responds. Some of the pupils look pleased with Pia's answer, while others, such as Jabir, who doesn't attend LTC, sigh. - Field notes from André School

In these cases, the teacher [Pia] can be said to take a whole-day perspective, which makes it possible for her to move the outdoor activity from school hours to LTC hours. The teacher does not take into account the fact that all pupils do not attend LTC. The teacher uses the whole-day perspective as a reason for why the pupils do not get any outdoor activities during school hours. In this example, the teacher's whole-day perspective excludes some pupils from the activities they want to participate in: Jabir is unable to be outside playing football during his school day, since his day does not include any time in LTC. This result is likely to have an impact on Jabir's opportunities to participate in social relations that are based on the activity of football, since he and other pupils who do not attend LTC are not given the opportunity to participate in this activity.

The limitation or difference in what pupils could choose to do at LTC and at school was also visible in other ways. The following example shows how restrictions in the school rules could affect what the pupils could choose to do during LTC hours and during school hours. This school rule was placed on a wall in a classroom. 
Example 2

School's materials are used during school hours and after-school care materials are used before and after school. (Exception if the class has decided otherwise.) From a list of school rules. - Field notes from Riverton School

This school rule states that there is a difference between the materials that the pupils are allowed to use during school hours and those they can use during LTC hours. By extension, this rule also makes the activities in the two types of schooling different from each other. One type of materials is used in school and another type is used in LTC. The availability of different materials affects the pupils’ opportunities to choose their activities. In our field notes, we had examples of how pupils were not allowed to use bicycles during school hours because they were 'only to be used in LTC' (André School), and of how certain books, papers and pens were kept in locked cabinets during LTC hours (a rule applied at both Riverton School and the Bear/Monkey), and thus were not available to use in leisure activities.

\section{Pupils' opportunities to choose who to be with}

The transition between school and LTC can also influence the pupils' opportunities to choose whom to be with. In LTC, pupils have opportunities to follow up on their social relations from school; they also have opportunities to establish new relationships with pupils who are not classmates. The groups in school and those in LTC are not always the same. An LTC group often consists of pupils from more than one school class, and not all pupils attend LTC. As a result, there are different conditions for social activities in school and in LTC. This fact, combined with the fact that pupils have different ending hours in LTC, sometimes results in pupils finding that the peers they want to be with or spend time with are unavailable for social interaction.

\section{Being with others but not with friends}

The following example shows how organization - activities and which pupils attend LTC can be a condition preventing pupils from maintaining their relationships with classmates.

\section{Example 3}

The pupils at the LTC centre are in the common room. They sit in groups at different tables. Some pupils draw, some are reading a book of facts together, and a few are crafting with beads. Samira moves between the tables and looks at what the different groups of pupils are doing. She stays and looks at what the others do, 
but does not engage in any activity. She doesn’t talk with anyone. Hasse, one of the teachers, askes her: 'What do you want to do?'. Samira shakes her head and says that she does not know because there is 'no one in her class at after-school care'. - Field notes from Bear/Monkey

The situation can be seen as full of opportunities to engage in social interaction since there is a variety of activities and relationships going on in the room. Samira could potentially seek access to any of these. The teacher, Hasse, also supports her in doing so. Nevertheless, Samira does not take part in any activity or group. Instead, her answer to Hasse’s question about what she wants to do is that there is 'no one in her class at leisure time centre'. In this case, the transition from school to LTC and the consequent changes in the group hinder Samira from engaging in social relations with the peers she wants to engage with. In the example above, Samira refers to her school class. Thus, the school class becomes a structural condition that is relevant to LTC. For Samira, her classmates are the ones she wants to have social relations with. The absence of classmates in this situation limits Samira's opportunities to participate in social relationships in LTC; she can be said to be excluded, or to exclude herself, because of this condition.

This example shows that 'who' is most important for Samira, while the teacher, Hasse, argues based on 'what'; that is, he is activity oriented. This finding can be compared with previous research on LTC that shows that educators often focus on activities in their support of pupils (Kjær 2005; Saar 2014).

\section{An opportunity to be with friends}

The transition from school to LTC can also bring opportunities to be with friends with whom the pupils desire to have relationships. In these cases, the changing groups are an opportunity to be with pupils who attend other school classes during school time. In the following example, Jovan talks about his friend Filip. Jovan attends first grade, while Filip is in preschool class. This means, according to Jovan, that they are unable to be with each other during school time.

\section{Example 4}

'He is five', says Jovan. 'Or five and a half', he corrects himself. 'Filip and I sometimes strangle each other [referring to a game that is played during free play in LTC that we have been discussing] in preschool class, I mean when we're at 
after-school care. We know each other in after-school care'. - Field notes from André School

In Jovan's case, LTC and the mixed age group there make it possible for him to engage in a desired social relationship. During school hours, this social relationship is not possible because of the organization at school; however, the changed conditions during LTC allow Jovan to be with his friend. The same conditions - that is, different groupings at school and at LTC - which in Samira's case (example 3) prevent her from engaging in desired social relations, here become an opportunity for desirable social relationships.

\section{Expectations of who you want to be with}

The changes in groups that occur in the different contexts of everyday transitions in school can, as shown, be both an opportunity and an obstacle, depending on the situation and on whom the pupils wish to engage with in social interaction. Thus, it is clear that the transition from school to LTC often involves changes in the group, thereby changing the conditions of pupils’ opportunities to form relationships with each other.

The organizations of school and of LTC also create different expectations of regarding whom pupils should want to have relations with. As shown above, Samira's school class constituted one such organizing element, since she referred to it as the basis of her social relationship building. Other organizing factors that can contribute to expectations of who wants to be with whom are age and grade. In the following example, there is a school break day, and the pupils are attending LTC for the whole day. The otherwise same-age units will be together for the whole day in a mixed-age group.

\section{Example 5}

Fewer pupils than expected have turned up, and when we arrive there are only a handful of pupils there. One of the teachers explains, 'There should, for instance, have been six third-graders here'. 'I am sooo disappointed!' Erik cries out and rolls his eyes. He is the only third grader that showed up today. Later, the small group of pupils and two of the teachers go to a nearby playground. Once in the park, most pupils climb the jungle gym. They play next to each other, but not with each other.

Two pupils on bikes come by. They go to the school, but are free today. 'Here comes another third-grader!' the teacher calls out in Erik’s direction. Erik and the 
newly arrived girl say 'Hi' to each other. They do not play, but start talking at a bit of a distance. The girl goes to the swings. 'Erik, do you want to play?' she asks. Erik doesn't really reply to her question. 'Are they the only ones at afterschool care today?' the girl asks one of the teachers. The teacher nods. 'Wasn't it nice that somebody from the third grade came by?' says the teacher to Erik. Erik nods. - Field notes from Riverton School

In this example, both Erik and the teacher express an expectation that Erik belongs with the other pupils in third grade, rather than with the younger pupils who are actually attending LTC that day. When the teacher explains that it there should have been other third-graders at LTC, Erik comments that he is 'sooo disappointed'. Although his statement can be seen as a joke (the excessive reaction and the roll of his eyes), the comment shows an expectation of belonging. Erik positions himself as one of the third-graders and forms a unit together with them. Later on, the teacher expresses a similar expectation. When some of the pupils who are not attending that day show up at the park, the teacher immediately addresses Erik - 'Here comes another third-grader'. Although Erik and the newly arrived girl do not interact more than the others did, the teacher expresses an expectation that they somehow belong together, and that her appearance means something positive for Erik. Other studies have shown that the group organization of school is an important part of the order that is created and becomes a condition for pupils’ social relationships (Almqvist 2011; Lago 2014). The school grouping permits certain relationships with classmates and limits the possibility of relationships with pupils from other classes. Even though LTC is an arena in which this organization can be broken and in which pupils can choose other groups to socialize with, the school class and other ways of school organizing teaching contribute to expectations of who should be together. Being in the same place does not necessarily mean that pupils are together, if the expectation is that one of the pupils belongs with someone else.

\section{Discussion}

This article examines pupils' opportunities to choose activities and maintain relationships during their school day, with a focus on transitions. The results show that the alteration in pupils' groups as they transition from school to LTC limits the opportunities pupils have to be with their friends. However, the different groups also provide pupils with an opportunity to be with different friends than the ones they associate with during the school day. Thus, the transition from school to LTC can be seen as both an opportunity and an obstacle in terms of making and keeping relations. The transition between school and LTC also brings creates 
limitations in opportunities to choose and continue with activities in the different settings. Even though the school and LTC are often in the same locations, clearly stated routines and rules in the school delimit what is possible to do in the different settings. The actors (both pupils and teacher) define the two settings in different ways (cf. Bulmer 1969), causing them to act and interact in different ways. Previous studies show that pupils often describe the differences between LTC and school, and that when pupils are asked to describe what an LTC is, they often compare it with school by saying that an LTC is 'something different' (Ackesjö and Landefrö 2014; Elvstrand and Närvänen 2016).

The Swedish curriculum clearly declares that a holistic approach is important, and that teachers in the two different educational settings (i.e. school and LTC) should cooperate, with the goal of providing the best learning opportunities to the child (National Agency of Education 2014). This analysis shows that some teachers separate the days and settings while others see school and LTC as integrated with each other. Whether teachers separate the two or not can be understood in terms of belonging, due to different conditions. Those who work as classroom teachers seldom work in the LTC; however, the teachers who work in the LTC during the afternoon also work in the school during school hours. Thus, some of the teachers see pupils in both educational settings and therefore can work from a whole-day perspective.

Pupils' experiences of the school day vary considerably, with some including school and LTC while others include only school. It is important to keep this differentiation in mind when planning school and LTC activities. An adult's perspective of what 'a day in school' means may be different from a pupil's perspective; in addition, one child's perspective may be different from another's. Thus, some pupils are relatively unaffected if an activity is moved from school to LTC, while other pupils may thereby miss an opportunity to participate in the activity and in the social relations linked to that activity. It is also important to keep the special conditions of LTC in mind: some pupils are there for several hours every afternoon, while others are just there for a short while and for a few days per week.

The results of this study also show that pupils and teachers have different perspectives on what is important in LTC. From the pupils' point of view, it is important to have the opportunity to choose their activity. As previous studies also show, being with friends is important, as are pupils’ opportunities to choose whom to be with (cf. Elvstrand and Närvänen 2014). 
In regard to social relations, the changes brought about by daily transitions between educational settings create conditions for different activities and changes in the group. These conditions can be both an opportunity and an obstacle as pupils attempt to build their desired social relations. The examples in this article also show that pupils may have very different experiences within the same educational setting. Thus, the teachers at school and at LTC must strive to gain an awareness of the special conditions in each educational setting, and of what kind of support pupils may need from them.

\section{References}

Ackesjö, Helena, and Anna Landefrö. 2014. "På spaning efter en gräns: Några barns perspektiv på skillnader mellan förskoleklassens och fritidshemmets verksamheter i Sverige.” Barn 3: 27-44.

Almquist, Ylva. 2011. “A Class of Origin: The School Class as a Social Context and Health Disparities in a Life-Course Perspective.” PhD diss., Stockholm University.

Andersson, Birgit. 2013. “Nya fritidspedagoger: I spänningsfältet mellan tradition och nya styrformer.” [New Leisure-time Pedagogues] PhD diss., Umeå University.

Atkinson, Paul, and William Housley. 2003. Interactionism. London: Sage Publications.

Bliding, Marie. 2004. "Inneslutandets och uteslutandets praktik: En studie av barns relationsarbete i skolan. [Practices of Inclusion and Exclusion.]” PhD diss., Göteborg University.

Blumer, Herbert. 1969. Symbolic Interactionism: Perspective and Method. Berkeley: University of California Press.

Broström, Stig, and Judith T. Wagner. 2003. “Transitions in Context: Models, Practicalities and Problems”. In Early Childhood Education in Five Nordic Countries: Perspectives on the Transition from Preschool to School, edited by Stig Broström and Judith T. Wagner, 27-36. Århus: Systime.

Charmaz, Kathy. 2014. Constructing Grounded Theory. Thousand Oaks: Sage Publications. Charon, Joel M. 2007. Symbolic Interactionism: An Introduction, an Interpretation, an Integration. New Jersey: Prentice-Hall. 
Corsaro, William A. 2003. “We're Friends, Right?”: Inside Kids' Cultures. Washington DC: Joseph Henry Press.

Corsaro, William A., Luisa Molinari, Kathryn Gold Hadley, and Heather Sugioka. 2003. “Keeping and Making Friends: Italian Pupils’ Transition from Preschool to Elementary School.” Social Psychology Quarterly 66 (3): 272-292.

Dahl, Marianne. 2014. “Fritidspedagogers handlingsrepertoar: Pedagogiskt arbete med barns olika relationer. [Leisure-Time Pedagogues’ Action Repertoire.]” PhD diss., Linné University.

Dehnæs Hogsnes, Hilde. 2014. “Barns muligheter for å erfare sammenhenger i overgang fra barnehage til skolefritidsordning.” Barn 3: 45-60.

Dockett, Sue, and Bob Perry. 2016. “Supporting Children’s Transition to School Age Care.” The Australian Educational Researcher 43 (3): 309-326. doi:10.1007/s13384-016-0202-y.

Dunlop, Aline-Wendy. 2007. “Bridging Research, Policy and Practice.” In Informing Transitions in the Early Years: Research, Policy and Practice, edited by Aline-Wendy Dunlop and Hilary Fabian, 151-168. Maidenhead: McGraw-Hill/Open University Press.

Elvstrand, Helene, and Lina Lago. 2016. “Elevers sociala relationer i fritidshem.” KAPET Karlstads universitets Pedagogiska Tidskrift 12 (1): 60-75.

Elvstrand, Helene, and Anna-Liisa Närvänen. 2014. "Pupils’ Participation in After-School Care: Visions and Realities.” Paper presented at ECER 2014, Porto, Portugal, September 1-5. Elvstrand, Helene, and Anna-Liisa Närvänen 2016. Children's Own Perspectives on Participation in Leisure-time Centers in Sweden. American Journal of Educational Research 4(6): 496-503. doi:10.12691/education-4-6-10.

Emerson, Robert M., Rachel I. Fretz, and Linda L Shaw. 1995. Writing Ethnographic Fieldnotes. Chicago: University of Chicago Press.

Fabian, Hilary. 2007. “Informing Transitions.” In Informing Transitions in the Early Years: Research, Policy and Practice, edited by Aline-Wendy Dunlop and Hilary Fabian, 3-17. Maidenhead: McGraw-Hill/Open University Press. 
Hammersley, Martyn, and Paul Atkinson. 2007. Ethnography: Principles in Practice. Milton Park, Abingdon, Oxon: Routledge.

Hogg, Michael A. and Graham M. Vaughan. 2010. Essentials of social psychology. Upper Saddle River, N.J.: Prentice Hall.

Hvitfeldt Stanek, Anja. 2011. “Børns fællesskaber og fællesskabernes betydning: Analyseret i indskolingen fra børnehave til 1. klasse og SFO. [Children’s Communities and Their Importance.]” PhD diss., Roskilde University.

Ihrskog, Maud. 2006. “Kompisar och Kamrater: Barns och ungas villkor för relationsskapande i vardagen. [Friends and Peers.]” PhD diss., Växjö University.

Johansson, Inge. 2007. "Horizontal Transitions: What Can It Mean for Pupils in the Early School Years?” In Informing Transitions in the Early Years: Research, Policy and Practice, edited by Aline-Wendy Dunlop and Hilary Fabian, 33-44. Maidenhead: McGraw-Hill/Open University Press.

Kjær, Bjørg. 2005. “Børn og barndom på fritidshjem: Et folkloristisk studie af fortolkning og forhandlingom barnlig identitet. [Children and Childhood at Leisure Time Centres.]” PhD diss., Göteborgs University.

Klerfelt, Anna, and Björn Haglund. 2014. "Presentation of Research on School-Age Educare in Sweden.” International Journal for Research on Extended Education 2 (1): 45-62.

Lago, Lina. 2014. ““Mellanklass kan man kalla det’: Om tid och meningsskapande vid övergången från förskoleklass till årskurs ett. ['You Could Say In-Between Class.']” PhD diss., Linköpings University.

Lam, Mei Seung, and Andrew Pollard. 2006. “A Conceptual Framework for Understanding Pupils as Agents in the Transition from Home to Kindergarten.” Early Years 26 (2): s. 123141. Doi: 10.1080/09575140600759906.

Ledger, Eileen, Anne B. Smith, and Peter Rich. 2000. "Friendships Over the Transition from Early Childhood Centre to School.” International Journal of Early Years Education 8 (1): 5769. Doi: 10.1080/096697600111743. 
Mayall, Barry. 2000. "Conversations with Children: Working with Generational Issues.” In Research with Pupils: Perspective and Practice, edited by Pia Christensen and Allison James, 120-135. London: RoutledgeFalmer.

National Agency of Education. 2014. Fritidshem: Skolverkets allmänna råd med kommentarer. Stockholm: Skolverket.

National Agency of Education. 2016a. "Pupils and Groups in Leisure Time Centers October 2015.” Accessed 2016-08-15.

National Agency of Education. 2016b. Curriculum for the Compulsory School, Preschool Class and the Recreation Centre, LGR11. Stockholm: Skolverket.

Niesel, Renate, and Wilfried Griebel. 2007. "Enhancing the Competence of Transition Systems through Co-construction.” In Informing Transitions in the Early Years: Research, Policy and Practice, edited by Aline-Wendy Dunlop and Hilary Fabian, 21-32. Maidenhead: McGraw-Hill/Open University Press.

Närvänen, Anna-Liisa, and Elisabet Näsman. 2007. “Time, Identity and Agency.” In Flexible Childhood?: Exploring Pupils' Welfare in Time and Space, edited by Helga Zeiher, Dympna Devine, Anne Trine Kjørholt, and Harriet Strandell, 69-92. Odense: University Press of Southern Denmark.

Saar, Tomas. 2014. “Towards a New Pedagogy in the After-School Setting.” European Early Childhood Education Research Journal 22 (2): 254-270. Doi:

10.1080/1350293X.2014.883722.

SFS 2010:800. The Swedish Education Act. Stockholm: Utbildningsdepartementet.

Skelton, Tracey. 2008. "Research with Pupils and Young people: Exploring the Tension Between Ethics, Competence and Participation.” Children's Geographies 6 (1): 21-36. Doi: 10.1080/14733280701791876.

Skånfors, Lovisa. 2010. “Tokens, Peer Context and Mobility in Preschool Pupils’ Positioning Work.” Nordisk barnehageforskning 3 (2): 41-52.

Thornberg, Robert. 2013. Det sociala livet i skolan: socialpsykologi för lärare. [The social life of the school]. Stockholm: Liber. 
Wagner, Judith T. 2003. “Introduction: International Perspectives and Nordic Contributions.” In Early Childhood Education in Five Nordic Countries: Perspectives on the Transition from Preschool to School, edited by Stig Broström and Judith T. Wagner, 11-25. Århus: Systime. Weller, Susie. 2007. “'Sticking With Your Mates?’: Pupils’s Friendship Trajectories During the Transition from Primary to Secondary School.” Children \& Society 21 (5): 339-351. Doi: 10.1111/j.1099-0860.2006.00056.x. 